Article

\title{
Changes in Photosynthetic Pigments, Total Phenolic Content, and Antioxidant Activity of Salvia coccinea Buc'hoz Ex Etl. Induced by Exogenous Salicylic Acid and Soil Salinity
}

\author{
Monika Grzeszczuk $^{1}$ (i), Piotr Salachna ${ }^{1, *(1)}$ and Edward Meller ${ }^{2}$ \\ 1 Department of Horticulture, West Pomeranian University of Technology, 3 Papieża Pawła VI Str., \\ Szczecin 71-459, Poland; monika.grzeszczuk@zut.edu.pl \\ 2 Department of Soil Science, Grassland Management and Environmental Chemistry, West Pomeranian \\ University of Technology, Słowackiego 17 Str., Szczecin 71-434, Poland; edward.meller@zut.edu.pl \\ * Correspondence: piotr.salachna@zut.edu.pl; Tel.: +48-91-4496-359
}

Received: 26 April 2018; Accepted: 28 May 2018; Published: 29 May 2018

\begin{abstract}
Salvia coccinea (Lamiaceae) is a promising source of potential antioxidants, and its extracts can be used in pharmaceutical industry, as well as in food products and cosmetics. Salicylic acid (SA) affects many physiological and metabolic processes in vascular plants under salinity stress. The aim of this study was to investigate the response of $S$. coccinea to either SA, or sodium chloride $(\mathrm{NaCl})$, or a combination of both. The plants were sprayed with a solution of 0.5 or $1.0 \mathrm{mM} \mathrm{SA}$ and watered with $0,100,200$, or $300 \mathrm{mM} \mathrm{NaCl}$. Exogenous application of SA increased the number of branches, fresh herbal weight, and total chlorophyll content vs control plants. Salinity-exposed plants showed reduced growth, content of photosynthetic pigments total polyphenols, and antioxidant activity. However, foliar application of SA relieved the adverse effects of $100 \mathrm{mM} \mathrm{NaCl}$, as demonstrated by increased number of branches, greater fresh herbal weight, higher content of total chlorophyll, total carotenoids, and total polyphenols, as well as antioxidant potential, detected using ferric-reducing ability of plasma (FRAP) and 2.2'-azino-bis(3-ethylbenzothiazoline-6-sulfonic acid) diammonium salt (ABTS), compared with untreated plants.
\end{abstract}

Keywords: scarlet sage; salicylic acid; $\mathrm{NaCl}$; polyphenols; FRAP; ABTS

\section{Introduction}

Salvia genus belongs to Lamiaceae family and includes approximately 900 species widely distributed throughout the world [1,2]. Many of them have been used for centuries in traditional medicine, as antihydrotics, tonics, antirheumatoids, antimicrobials, antispasmodics, antiseptics, astringents, digestives, anti-inflammatories, carminatives, and chronic painkillers, and also as a spice for flavoring and preserving foods, and in cosmetics and perfumes [3-5]. Several studies identified Salvia genus as one of the most valuable sources of natural antioxidants [6,7]. The main chemical components identified in sage are essential oils, hydroxycinnamic acid derivatives, phenolic diterpenes, triterpenes, flavonoids, phenolic glycosides, and polysaccharides [3,8]. Carnosol and carnosic acid (phenolic diterpenes), rosmarinic acid, caffeic acid, ferulic acid and chlorogenic acid (hydroxycinnamic acid derivatives), salvianolic acid (dimer of rosmarinic acid), and also some essential oil compounds (camphor, 1, 8-cineole, $\alpha$-thujone, $\beta$-thujone) and flavonoids (flavones of apigenin and luteolin, and their hydroxylated derivates) were identified as the major antioxidants present in sage $[4,7,9]$. These antioxidants help in maintaining health, and protect against atherosclerosis, stroke, 
diabetes, neurodegenerative diseases, and cancer. Their properties made them highly interesting to scientists, food manufacturers, and consumers [10-12].

The high food demand of growing human population requires a reduction of the harmful effects of salinity that is as one of the major factors affecting plant crop productivity worldwide [13-15]. Using exogenous salicylic acid (SA) for this purpose has been proposed by many scientists $[16,17]$. SA is a phytohormone (phenolic-type regulator, a non-enzymatic antioxidant) and the most biologically active mediator of plant biotic and abiotic stress responses [18-20]. It affects plant growth and development, seed germination, thermogenesis, stomatal regulation and photosynthesis, ion uptake, as well as antioxidant activity [21-23]. Exogenous application of SA enhances tolerance to salt stress in several medicinal plant species [24,25]. However, plant response to SA may differ even within the same species, and depends on its dose and application method, plant age, its nutritional status, and environmental conditions [26]. Sahar et al. [27] reported that salicylic acid treatment increased proline accumulation in the leaves of Salvia officinalis grown under salinity stress, and increasing levels of proline are known to boost resistance to salt stress. The mechanisms of the beneficial effects of SA application in sage remain largely unknown.

One of the more interesting sages is Salvia coccinea Buc'hoz ex Etl. (scarlet sage). It is an herbaceous annual or perennial plant, probably native to Mexico, with paired aromatic leaves and red flowers in whorls, forming simple or branched racemes. This species is an excellent ornamental plant for public green areas and private gardens, and is moderately tolerant to salinity [28,29]. S. coccinea is described in the scientific literature as a rich source of antioxidant polyphenols with therapeutic potential [30-32]. However, to our knowledge, the effects of growing conditions on the antioxidant activity in S. coccinea remain unknown. Likewise, no information on growth parameters or physiological response of S. coccinea to exogenous SA has been published. Thus, the present study aimed to investigate the effects of applying SA and sodium chloride on growth, pigments content, total polyphenols, and antioxidant activity of S. coccinea.

\section{Results and Discussion}

\subsection{Growth Attributes}

Salt stress affects all major processes and plant metabolic pathways and reduces plant quality. In this study, salt stress at $300 \mathrm{mM} \mathrm{NaCl}$ negatively affected the number of branches and fresh weight of the aboveground parts of a plant determined at the beginning of flowering (fresh herbal weight) (Figure 1).

Moderate salinity (25-75 mM) was reported to stimulate plant growth in S. coccinea, but high $\mathrm{NaCl}$ concentration negatively affected morphological features [29]. Exogenous application of SA increased the number of branches and fresh herbal weight under non-stressed conditions as compared to control plants. Increased biomass resulting from SA treatment was also reported in other species such as pepper [21], ginger [33], and artichoke [25]. The growth-promoting effects may be due to SA-mediated enhancement of the efficiency of photosynthesis, transpiration, and uptake of nutrients [34]. SA may also influence plant hormonal status and improve plant growth by controlling their metabolism [26,35]. Our study showed the highest fresh herbal weight in plants treated with $0.5 \mathrm{mM} \mathrm{SA}$ and $100 \mathrm{mM} \mathrm{NaCl}$. This confirms previous reports that adverse effect of salt stress on plant growth may be effectively reduced by exogenous SA [23,36,37]. 

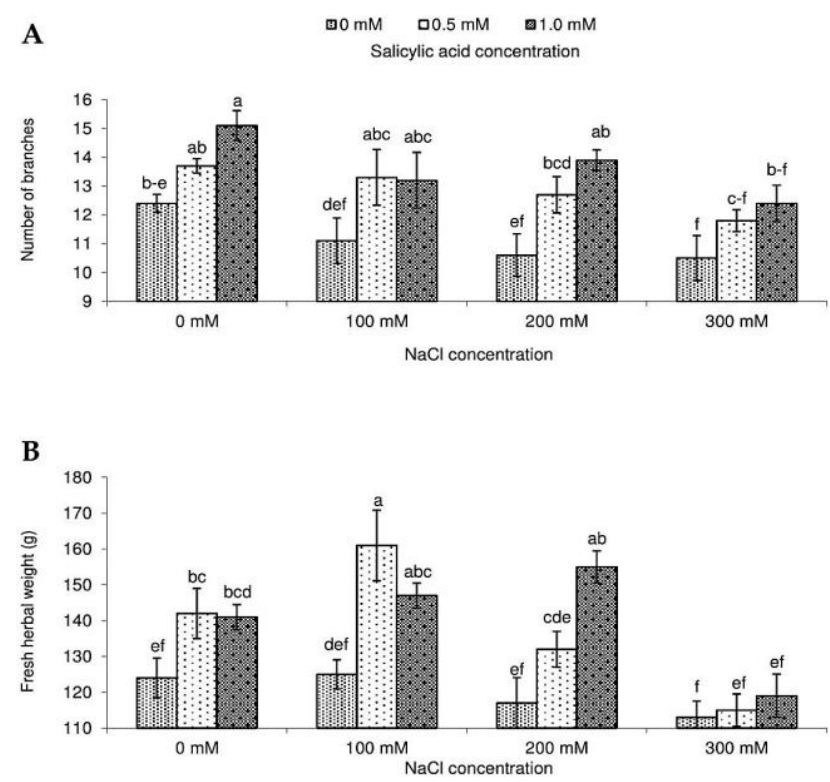

Figure 1. Effect of different levels of sodium chloride $(\mathrm{NaCl})$, salicylic acid $(\mathrm{SA})$, and interaction between $\mathrm{NaCl}$ and $\mathrm{SA}$ on the number of branches (A) and fresh herbal weight (B) of Salvia coccinea. Bars within a chart with the same lower-case letter are not significantly different at $p \leq 0.05$. Values represent the means of three replications \pm standard deviations.

\subsection{Photosynthetic Pigment Contents}

Salt stress inhibits chlorophyll and total carotenoid concentrations in the leaves of many crop plants [38]. According to Gengmao et al. [39], the content of photosynthetic pigments in Salvia miltiorrhiza leaves decreased with increasing salinity. It is also visible in the results of our study. The content of chlorophyll $a, b$, total chlorophylls, and total carotenoids decreased significantly with increasing salinity (Figure 2).

SA treatment induces an increase in photosynthetic efficiency in chloroplast, resulting in higher content of chlorophylls in plant tissues [22]. Rady and Mohamed [17] reported that SA significantly enhanced the content of these pigments in the leaves of common bean plants grown in moderately salinized soil. In our study, SA significantly increased chlorophyll $a$ and total chlorophyll content in plants not exposed to $\mathrm{NaCl}$ (Figure 2). For salinized soil, the most effective SA concentration was $1.0 \mathrm{mM}$, and it was especially evident when the concentration of $\mathrm{NaCl}$ was $100 \mathrm{mM}$. Similar relations occurred for chlorophyll $b$. However, there were no significant differences in chlorophyll $b$ content between plants treated with $0 \mathrm{mM} \mathrm{NaCl}+0.5 \mathrm{mM} \mathrm{SA}$, and $100 \mathrm{mM} \mathrm{NaCl}+1.0 \mathrm{mM} \mathrm{SA}$.

Chlorophyll $a / b$ ratio was the lowest for the control object, and it dropped with growing salinity (Figure 3). As for the effect of SA concentration on chlorophyll $a / b$ ratio, the highest value was noted for the control, and it diminished with raising SA concentration. Moreover, an interaction between the analyzed experimental factors showed the highest chlorophyll $a / b$ ratio for $100 \mathrm{mM} \mathrm{NaCl}+0 \mathrm{mM} \mathrm{SA}$ and the lowest for $0 \mathrm{mM} \mathrm{NaCl}+1.0 \mathrm{mMSA}$. Similarly as for chlorophylls, the highest carotenoid content transpired in the variant without $\mathrm{NaCl}$ treated with $0.5 \mathrm{mM} \mathrm{SA}$ (Figure 2). The most evident effect of SA on the content of total carotenoids in plants grown in salinized soil was detected for the combination $100 \mathrm{mM} \mathrm{NaCl}+1.0 \mathrm{mM} \mathrm{SA}$. An analogous situation was noted for the chlorophyll/carotenoid ratio (Figure 3). Some authors reported that lowering of chlorophyll $a$ to chlorophyll $b$ ratio indicates photoinhibition due to damage of photosystem II [40]. Moreover, the changes in the chlorophyll total to carotenoids ratio may be one of the symptoms of oxidative stress [41]. 

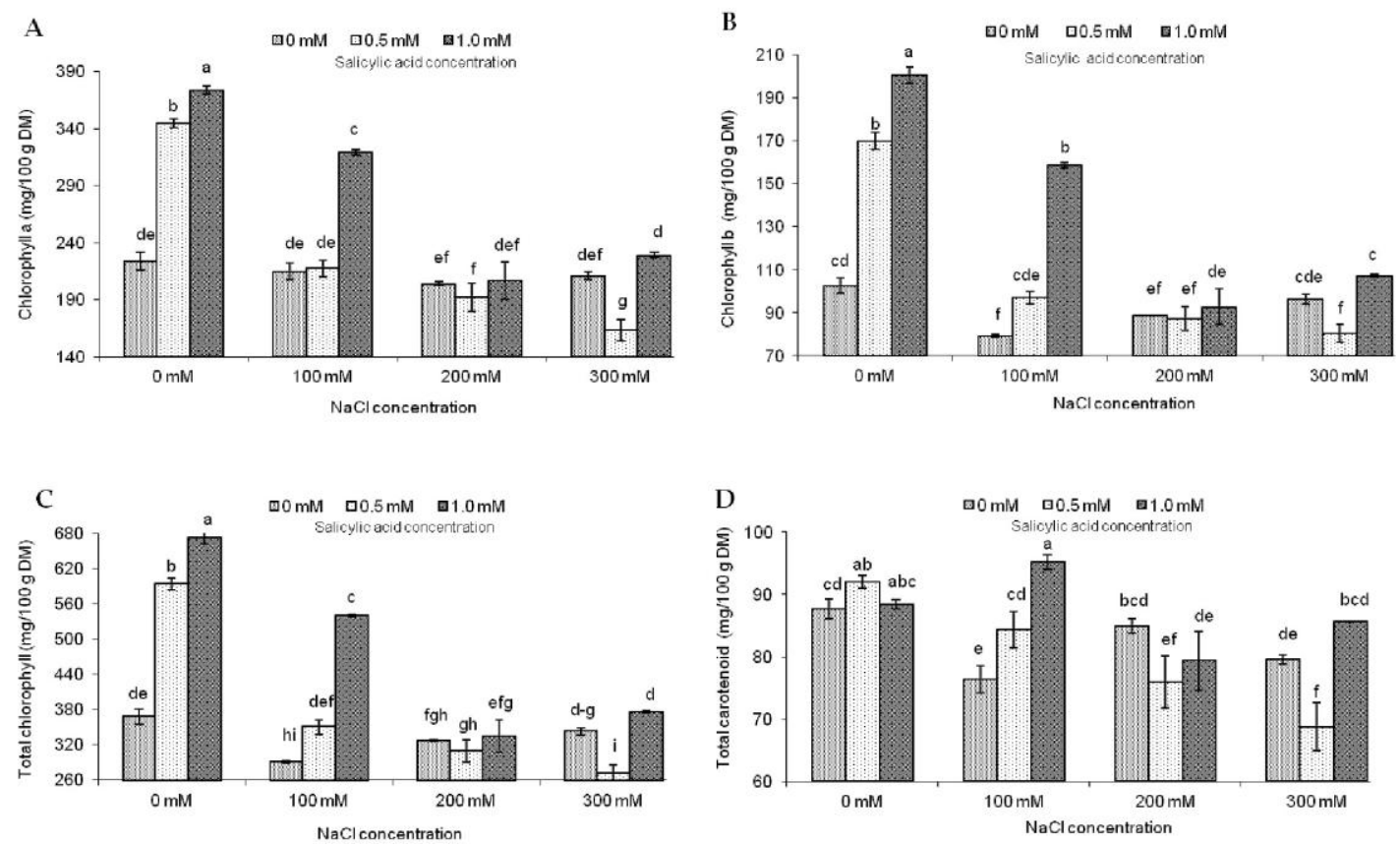

Figure 2. Effect of different levels of sodium chloride ( $\mathrm{NaCl}$ ), salicylic acid (SA), and interaction $\mathrm{NaCl}$ and SA on chlorophyll $a(\mathbf{A})$, chlorophyll $b(\mathbf{B})$, total chlorophyll (C), and total carotenoids (D) of Salvia coccinea. Bars within a chart with the same lower-case letter are not significantly different at $p \leq 0.05$. Values represent the means of three replications \pm standard deviations.
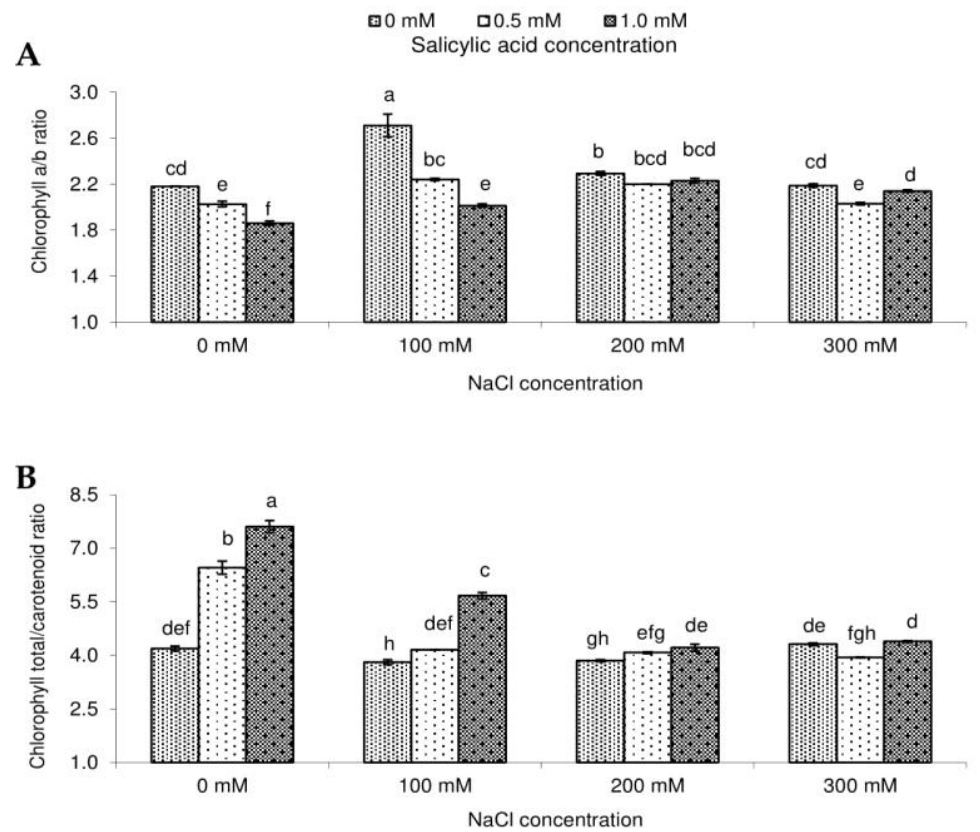

Figure 3. Effect of different levels of sodium chloride $(\mathrm{NaCl})$, salicylic acid (SA), and interaction between $\mathrm{NaCl}$ and SA on the ratio of chlorophyll $a$ to chlorophyll $b(\mathbf{A})$, and the ratio of total chlorophyll to carotenoids (B) of Salvia coccinea. Bars within a chart with the same lower- case letter are not significantly different at $p \leq 0.05$. Values represent the means of three replications \pm standard deviations. 


\subsection{Total Polyphenol Content and Antioxidant Activity}

Although SA and salt stress significantly affected leaf polyphenol content and antioxidant activity of Salvia coccinea (Figures 4 and 5). The content of total polyphenols was the highest (78.81 mg GAE/g $\mathrm{DM}$ ) in the leaves in the control object and the lowest (45.38 GAE/g DM) in the plants watered with $100 \mathrm{mM} \mathrm{NaCl}$ and not treated with SA. FRAP assay used for determining antioxidant activity in S. coccinea leaves treated with $\mathrm{NaCl}$ and SA showed the highest values (1001.94 mg TE/g DM) in the control plants. We detected the greatest antioxidant potential (1461.56 mg TE/g DM) also assessed by FRAP in the plants treated with $200 \mathrm{mM} \mathrm{NaCl}$ and $0.5 \mathrm{mM}$ SA.

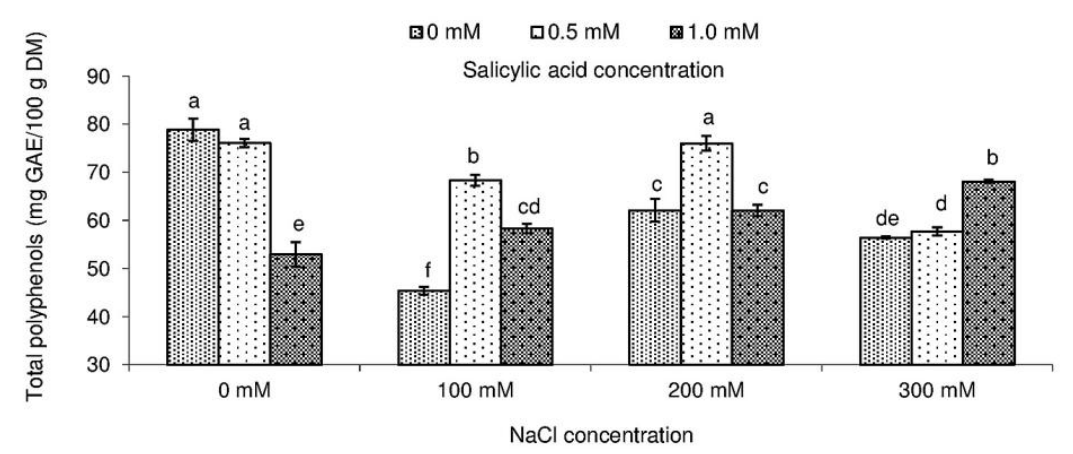

Figure 4. Effect of different levels of sodium chloride $(\mathrm{NaCl})$, salicylic acid (SA), and interaction between $\mathrm{NaCl}$ and SA on total phenolic content of Salvia coccinea. Bars within a chart with the same lower-case letter are not significantly different at $p \leq 0.05$. Values represent the means of three replications \pm standard deviations.

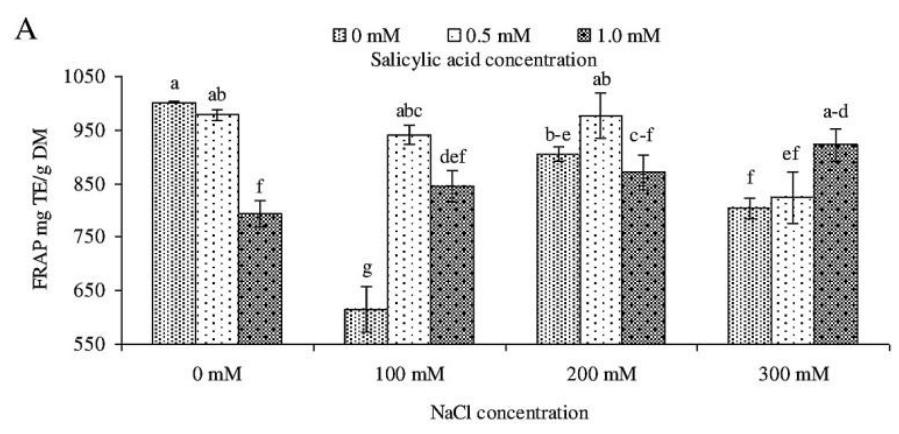

B

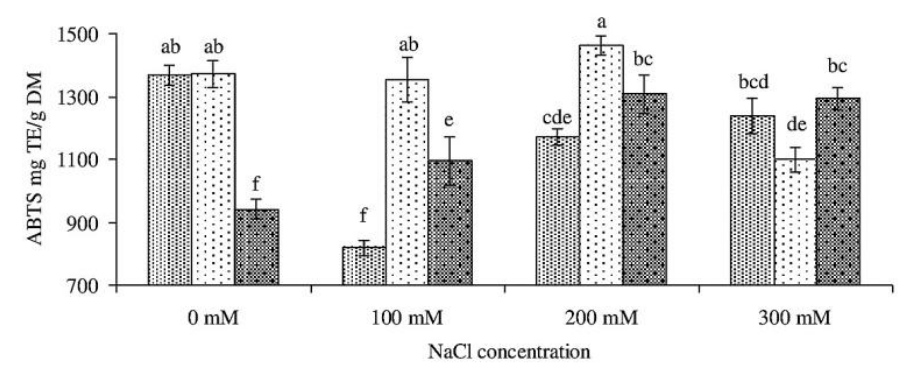

Figure 5. Effect of different levels of sodium chloride $(\mathrm{NaCl})$, salicylic acid (SA), and interaction between $\mathrm{NaCl}$ and SA on antioxidant activity of Salvia coccinea through ferric-reducing ability of plasma (FRAP) scavenging activity (A), and 2,2'-azino-bis(3-ethylbenzothiazoline-6-sulfonic acid) diammonium salt (ABTS) (B) assays. Bars within a chart with the same lower-case letter are not significantly different at $p \leq 0.05$. Values represent the means of three replications \pm standard deviations. 
The results which we obtained in total polyphenols were higher compared with the results of Muráriková et al. [9], who reported polyphenol content of $34.08 \mathrm{mg}$ GAE/g DM in S. coccinea plants. In the study of Bilgin et al. [32], total polyphenol content in S. coccinea leaves ranged from $3.48(50 \% \mathrm{MeOH})$ to $43.18 \mathrm{mg} \mathrm{GAE} / \mathrm{g} \mathrm{DM}(100 \% \mathrm{MeOH})$, depending on the hydroalcoholic solvent ratio. Pop et al. [1] used two different methods of plant extraction and reported the values to change from 24.90 to $36.72 \mathrm{mg} \mathrm{GAE} / \mathrm{g}$ DM in the leaves of Salvia officinalis ('Tricolor' and 'Purpurascens'), from 19.84 to 28.90 in Salvia lavanduifolia, and 7.68 to 11.23 in Salvia elegans. Tehami et al. [42] found that total polyphenols in the leaves of Salvia argentea amounted to $71.80 \mathrm{mg}$ GAE/g DM (aqueous extract) and $87.13 \mathrm{mg}$ GAE/g DM (methanolic extract). Lamien-Meda et al. [3] expressed total polyphenol content in $S$. officinalis aerial parts in $\mathrm{mg}$ of catechin equivalents that varied from 50 to $89 \mathrm{mg}$ CAE/g DM. According to Lamien-Meda et al. [3] and Farhat et al. [4], the quantitative variations of polyphenols in the plant material may be due not only to the extraction and quantification methods, but also to geographical or climatic factors, vegetative phase, genotypes, etc. Moreover, polyphenol synthesis and their accumulation are generally stimulated in response to biotic/abiotic stresses, such as salinity [43,44]. Valifard et al. [45] showed that both phenolic content and antioxidant activity in S. mirzayanii leaves increased until mild salinity stress $(6.8 \mathrm{dS} / \mathrm{m})$, but declined at high salinity (9.1 dS/m). Also, Taârit et al. [44] reported that at 25 and $50 \mathrm{mM} \mathrm{NaCl}$ total polyphenol content and antioxidant activity were higher than in control plants but declined with an increase in $\mathrm{NaCl}$ from 50 to $75 \mathrm{mM}$. Our results show the same tendency for total polyphenol content, FRAP, and ABTS antioxidant activity with increasing salinity. However, at the highest $\mathrm{NaCl}$ concentration (300 $\mathrm{mM})$, these parameters were lower than at $200 \mathrm{mM} \mathrm{NaCl}$ (Figures 4 and 5).

Plants exposed to $100 \mathrm{mM} \mathrm{NaCl}$ and sprayed with SA at both concentrations (0.5 and $1.0 \mathrm{mM})$ showed significantly higher total phenolic content, as well as leaf antioxidant activity, as determined by both FRAP and ABTS. Also, Thiruvengadam et al. [46] reported that plant treatment with salicylic acid results in higher total polyphenol content. Results from this experiment clearly indicated that exogenous SA increases antioxidant activity in plants under moderate salinity levels. The outcomes of our study corroborate recent findings that high antioxidant activity in stressed plants is a result of increasing activity of antioxidant enzymes that mitigate the negative effect of reactive oxygen species $[13,47]$.

\section{Materials and Methods}

\subsection{Plant Culture, Treatment, and Measurement of Growth Parameters}

Seeds of Salvia coccinea were obtained from Breeding and Seed Company W. Legutko (Jutrosin, Poland). Before germination, the seeds were surface-sterilized in $0.2 \%$ sodium hypochlorite solution for $10 \mathrm{~min}$, and then rinsed several times with distilled water. They were sown on 30th March 2014 into boxes filled with substrate base (Klasmann-Deilmann, Geeste, Germany), in controlled-environment glasshouse $\left(21 / 17^{\circ} \mathrm{C}\right.$ day /night). After three weeks, uniform seedlings were transferred into pots $8 \mathrm{~cm}$ in diameter, filled with TS1 plant substrate (Klasmann-Deilmann). On 28 May 2014, single seedlings were transferred into black plastic pots of $17 \mathrm{~cm}$ in diameter and $2 \mathrm{dm}^{3}$ capacity. The substrate was deacidified peat at $\mathrm{pH}$ 6.5, mixed with Yara Mila Complex fertilizer (Yara International ASA, Oslo, Norway) containing $12 \% \mathrm{~N}, 11 \% \mathrm{P}_{2} \mathrm{O}_{5}, 18 \% \mathrm{~K}_{2} \mathrm{O}, 2.7 \% \mathrm{MgO}, 8 \% \mathrm{~S}, 0.015 \% \mathrm{~B}, 0.2 \% \mathrm{Fe}, 0.02 \% \mathrm{Mn}$, and $0.02 \% \mathrm{Zn}$, used at $2.5 \mathrm{~g} / \mathrm{dm}^{3}$. The pots were transferred to a non-heated tunnel covered with double layer of plastic located in the area of West Pomeranian University of Technology in Szczecin $\left(53^{\circ} 25^{\prime} \mathrm{N}, 14^{\circ} 32^{\prime} \mathrm{E} ; 25 \mathrm{~m}\right.$ a.s.1.). Mean monthly air temperature inside the tunnel was May $18.9^{\circ} \mathrm{C}$, June $19.7^{\circ} \mathrm{C}$, July $24.1^{\circ} \mathrm{C}$, and August $19.6^{\circ} \mathrm{C}$.

Salicylic acid SA (Sigma Aldrich, St. Louis, MO, USA) was dissolved in a small amount of ethanol (Chempur, Piekary Ślaskie, Poland). The plants were sprayed early in the morning with 0.5 or $1 \mathrm{mM}$ SA three times, every seven days, starting from 1 June 2014. Each time individual plants were sprayed with about $20 \mathrm{~cm}^{3}$ of the solution. The solution was supplemented with Silwet Gold wetting agent 
(Momentive Performance, Wilton, CT, USA). The plants exposed to salt stress were irrigated with a solution of sodium chloride $\mathrm{NaCl}$ (Chempur, Poland), four times, every five days from 1 July 2014, using $250 \mathrm{~mL}$ of the solution per plant per application. The following $\mathrm{NaCl}$ concentrations were used: 100, 200, and $300 \mathrm{mM}$. Control plants were irrigated with tap water with electrical conductivity (EC) $0.25 \mathrm{mS} \cdot \mathrm{cm}^{-1}$. Each treatment had four replicates, and each replicate included five plants. On 20 September 2014, at the beginning of flowering, the plants were harvested for determination of growth parameters. The number of branches and fresh herbal weight, e.g., the total fresh weight of the aboveground parts of a plant (leaves, stems, and inflorescences) were recorded. Leaves were dried for four weeks at $25-30{ }^{\circ} \mathrm{C}$, then placed into paper bags and stored at room temperature in the dark until use. Chemical analyses of dried material were performed within two months from harvest.

\subsection{Photosynthetic Pigment Determination}

The content of chlorophylls and carotenoids was determined using a spectrophotometric method described by Lichtenthaler and Wellburn [48] with some modifications. The weighted (with an accuracy of $0.0001 \mathrm{~g}$ ) samples of ground dried leaves (about $0.5 \mathrm{~g}$ ) were triturated in the presence of $80 \%(v / v)$ aqueous acetone, and transferred in $80 \%$ acetone to $50 \mathrm{~cm}^{3}$ volume measuring flask. The flasks with the samples were placed in an ultrasonic cleaner for $5 \mathrm{~min}$. Then the extract samples $(7 \mathrm{~mL})$ were centrifuged at 13,000 rpm for $10 \mathrm{~min}$. The supernatant was transferred to a cuvette, and the absorbance was measured at 441, 646, 652, and 663 nm using a Helios Gamma Spectrophotometer (Thermo Spectronic, Cambridge, UK).

Equations used for the calculations are presented below:

$$
\begin{gathered}
\text { Chlorophyll a }=12.21 \times \mathrm{E}_{663}-2.81 \times \mathrm{E}_{646,} \\
\text { Chlorophyll b=20.13 } \times \mathrm{E}_{646}-5.03 \times \mathrm{E}_{663,} \\
\text { Total chlorophyll }=27.8 \times \mathrm{E}_{652,} \\
\text { Total carotenoids }=\left(1000 \times \mathrm{E}_{441}\right)-3.27 \times\left(12.21 \times \mathrm{E}_{663}-2.81 \times \mathrm{E}_{646}\right)-104 \times\left(20.13 \times \mathrm{E}_{646}-5.03 \times \mathrm{E}_{663}\right) .
\end{gathered}
$$

Chlorophyll and carotenoid contents were expressed in $\mathrm{mg} / 100 \mathrm{~g}$ of dry matter after correction for moisture content (drying the samples at $105^{\circ} \mathrm{C}$ to constant weight). Each analysis was carried out in triplicate.

\subsection{Determination of Total Polyphenol Content and Antioxidant Activity}

\subsubsection{Preparation of Plant Extracts}

Plant extracts used for determination of total polyphenol content and antioxidant activity were reported as proposed by Wojdyło et al. [49], with some modifications as described in the previous work [50]. A sample of $1 \mathrm{~g}$ dried ground leaves of Salvia coccinea was treated with $80 \%$ methanol $(\mathrm{MeOH})$ to a final volume of $100 \mathrm{~mL}$. The mixtures were ultrasonicated for $30 \mathrm{~min}(2 \times 15 \mathrm{~min})$ and then left to stand for $24 \mathrm{~h}$ at room temperature $\left(\sim 20^{\circ} \mathrm{C}\right)$. The resulting extracts were filtered through Whatman No. 1 filter paper. Then, the filtrates were centrifuged for $10 \mathrm{~min}$ at $1500 \mathrm{rpm}$. All the extractions were prepared in triplicate. The extracts were kept at $4{ }^{\circ} \mathrm{C}$ and analyzed within $24 \mathrm{~h}$.

\subsubsection{Total Polyphenol Content}

Content of total polyphenols was analyzed spectrophotometrically using the Folin-Ciocalteu colorimetric procedure, according to the method described by Wojdyło et al. [49]. The plant extract $(100 \mu \mathrm{L}), 0.2 \mathrm{~mL}$ of Folin-Ciocalteu reagent, $2 \mathrm{~mL}$ of deionized water, and $1 \mathrm{~mL}$ of $20 \%$ sodium carbonate, were mixed and incubated for $1 \mathrm{~h}$ at room temperature in darkness. Then, absorbance was measured at $760 \mathrm{~nm}$ and gallic acid (GAE) was used for calibration of the standard curve. Total polyphenols were calculated as mg GAE equivalent per $g$ of dry matter sample (DM). 


\subsubsection{Determination of Ferric-Reducing Antioxidant Power (FRAP)}

The antioxidant activity of the samples was also determined using the ferric-reducing ability of plasma FRAP method reported by Wojdyło et al. [49]. FRAP reagent was prepared freshly by mixing acetate buffer (300 mM, pH 3.6), a solution of $10 \mathrm{mM}$ TPTZ (2,4,6-tris(2-pyridyl)-s-triazine) in $40 \mathrm{mM}$ $\mathrm{HCl}$, and $20 \mathrm{mM} \mathrm{FeCl} 3 \cdot 6 \mathrm{H}_{2} \mathrm{O}$ (iron(III) chloride hexahydrate) at 10:1:1 (v/v/v), and warming it at $37^{\circ} \mathrm{C}$ before use. For the determination of antioxidant activity, $2.7 \mathrm{~mL}$ of FRAP reagent was mixed with $0.3 \mathrm{~mL}$ of the sample solution. The absorbance was measured spectrophotometrically at $593 \mathrm{~nm}$ after four min. The standard curve was prepared using different Trolox concentrations. FRAP activity was calculated as mg TE per $\mathrm{g}$ DM.

\subsubsection{Determination of Free Radical-Scavenging Ability Using a Stable ABTS Radical Cation}

Free radical-scavenging activity was carried out according to the ABTS radical cation decolorization procedure reported by Chew et al. [51], Wojdyło et al. [49], and Re et al. [52] with some modifications as described in the previous work [50]. ABTS (2,2'-azino-bis(3-ethylbenzothiazoline-6-sulfonic acid) diammonium salt was dissolved in deionized water to a $7 \mathrm{mM}$ concentration. ABTS radical cation $\left(\mathrm{ABTS}^{\bullet+}\right.$ ) was generated by mixing ABTS stock solution with $2.45 \mathrm{mM}$ potassium peroxodisulfate. The reagent was kept in the dark at room temperature for $16 \mathrm{~h}$ before using. Subsequently, the ABTS ${ }^{\bullet+}$ solution was diluted with PBS (phosphate buffered saline, $\mathrm{pH} 7.4$ ) to an absorbance of $0.7( \pm 0.02)$ at $734 \mathrm{~nm}$ before usage. The reaction was initiated by adding $3 \mathrm{~mL}$ of diluted ABTS ${ }^{\bullet+}$ solution $\left(\mathrm{A}_{734}=0.7 \pm 0.02\right)$ to $300 \mu \mathrm{L}$ of methanolic plant extracts. The absorbance was measured at $734 \mathrm{~nm}$, exactly $6 \mathrm{~min}$ after mixing. The results were calculated from the calibration curve using Trolox as standard, and expressed as mg TE per g dry weight sample.

\subsection{Statistical Analysis}

The experiment was set up in the system of complete randomization. The results were statistically analyzed by means of analysis of variance for 2-factor experiments using STATISTICA 13.0 software (Statsoft, Cracov, Poland). After checking the good fit of the model, post hoc comparison was done using the Tukey's multiple range test.

\section{Conclusions}

Salvia coccinea is a promising source of potential antioxidants, and its extracts can be used in the pharmaceutical industry, as well as in food products and cosmetics. S. coccinea plants responded positively to salicylic acid (SA) application. SA stimulated the growth of plants via improved the number of branches, fresh herbal weight, and total chlorophyll content. Salt stress reduced growth, leaf pigment content and total polyphenols in plants. However, foliar application of SA relieved the adverse effects of $100 \mathrm{mM} \mathrm{NaCl}$, as demonstrated by increased biomass, content of photosynthetic pigments, and total polyphenols, as well as antioxidant potential by FRAP and ABTS.

So, we do agree with the statement that salt-stressed plants might represent potential sources of phenolic compounds for economical use. Additional SA treatment may further increase their content in plants grown under mild salinity stress and also enhance plant antioxidant activity and growth parameters.

Author Contributions: M.G. performed the analysis of laboratory, analyzed the data and wrote the manuscript; P.S. performed the experiments; analyzed the data and wrote the manuscript; E.M. contributed to the revisions of the manuscript; All authors were responsible for processing information and manuscript writing. All authors read and approved the final manuscript.

Funding: This research received no external funding

Acknowledgments: The study was supported by the Polish Ministry of Science and Higher Education (Project UPB 518-07-014-3176-02/18 ZUT).

Conflicts of Interest: The authors declare no conflict of interest. 


\section{References}

1. Pop (Cuceu), A.-V.; Tofană, M.; Socaci, S.A.; Nagy, M.; Borş, M.-D.; Salanţă, L.; Vlaic, R. Studies on total polyphenols content and antioxidant activity of methanolic extracts from selected Salvia species. Bull. UASVM Food Sci. Technol. 2015, 72, 86-90. [CrossRef]

2. Yadav, A.; Joshi, A.; Kothari, S.L.; Kachhwaha, S.; Purohit, S. Medicinal, nutritional and industrial applications of Salvia species: A revisit. Int. J. Pharm. Sci. Rev. Res. 2017, 43, 27-37.

3. Lamien-Meda, A.; Nell, M.; Lohwasser, U.; Börner, A.; Franz, C.; Novak, J. Investigation of antioxidant and rosmarinic acid variation in the sage collection of the genebank in gatersleben. J. Agric. Food Chem. 2010, 58, 3813-3819. [CrossRef] [PubMed]

4. Farhat, M.B.; Landoulsi, A.; Chaouch-Hamada, R.; Sotomayor, J.A.; Jordán, M.J. Characterization and quantification of phenolic compounds and antioxidant properties of Salvia species growing in different habitats. Ind. Crops Prod. 2013, 49, 904-914. [CrossRef]

5. Hamidpour, R.; Hamidpour, S.; Hamidpour, M.; Shahlari, M. Chemistry, pharmacology and medicinal property of sage (Salvia) to prevent and cure illnesses such as obesity, diabetes, depression, dementia, lupus, autism, heart disease and cancer. Glob. J. Med. Res. 2013, 13, 1-8. [CrossRef] [PubMed]

6. Roby, M.H.H.; Sarhan, M.A.; Selim, K.A.H.; Khalel, K.I. Evaluation of antioxidant activity, total phenols and phenolic compounds in thyme (Thymus vulgaris L.), sage (Salvia officinalis L.), and marjoram (Origanum majorana L.) extracts. Ind. Crops Prod. 2013, 43, 827-831. [CrossRef]

7. Lu, Y.; Foo, L.Y. Polyphenolics of Salvia-A review. Phytochemistry 2002, 59, 117-140. [CrossRef]

8. Wu, Y.-B.; Ni, Z.-Y.; Shi, Q.-W.; Dong, M.; Kiyota, H.; Gu, Y.-C.; Cong, B. Constituents from Salvia species and their biological activities. Chem. Rev. 2012, 112, 5967-6026. [CrossRef] [PubMed]

9. Muráriková, A.; Kaffková, K.; Raab, S.; Neugebauerová, J. Evaluation of content of phenolics in Salvia species cultivated in South Moravian Region. Acta Fac. Pharm. Univ. Comen. 2015, 62, 18-22.

10. Kumaran, A.; Karunakaran, R.J. In vitro antioxidant activities of methanol extracts of five Phyllanthus species from India. Food Sci. Technol. 2007, 40, 344-352. [CrossRef]

11. Ghasemnezhad, M.; Sherafati, M.; Payvast, G.A. Variation in phenolic compounds, ascorbic acid and antioxidant activity of five coloured bell pepper (Capsicum annum) fruits at two different harvest times. J. Funct. Foods 2011, 3, 44-49. [CrossRef]

12. Rauter, A.P.; Dias, C.; Martins, A.; Branco, I.; Neng, N.R.; Nogueira, J.M.; Goulart, M.; Silva, F.V.M.; Justino, J.; Trevitt, C.; et al. Non-toxic Salvia sclareoides Brot. extracts as a source of functional food ingredients: phenolic profile, antioxidant activity and prion binding properties. Food Chem. 2012, 132, 1930-1935. [CrossRef]

13. Esan, A.M.; Masisi, K.; Dada, F.A.; Olaiya, C.O. Comparative effects of indole acetic acid and salicylic acid onoxidative stress marker and antioxidant potential of okra (Abelmoschus esculentus) fruit under salinity stress. Sci. Hortic. 2017, 216, 278-283. [CrossRef]

14. Balliu, A.; Sallaku, G.; Rewald, B. AMF inoculation enhances growth and improves the nutrient uptake rates of transplanted, salt-stressed tomato seedlings. Sustainability 2015, 7, 15967-15981. [CrossRef]

15. Martinez, V.; Nieves-Cordones, M.; Lopez-Delacalle, M.; Rodenas, R.; Mestre, T.C.; Garcia-Sanchez, F.; Rubio, F.; Notes, P.A.; Mittler, R.; Rivero, R.M. Tolerance to stress combination in tomato plants: New insights in the protective role of melatonin. Molecules 2018, 23, 535. [CrossRef] [PubMed]

16. Simaei, M.; Khavari-Nejad, R.A.; Bernard, F. Exogenous application of salicylic acid and nitric oxide on the ionic contents and enzymatic activities in NaCl-stressed soybean plants. Am. J. Plant. Sci. 2012, 3, 1495-1503. [CrossRef]

17. Rady, M.M.; Mohamed, G.F. Modulation of salt stress effects on the growth, physio-chemical attributes and yields of Phaseolus vulgaris L. plants by the combined application of salicylic acid and Moringa oleifera leaf extract. Sci. Hortic. 2015, 193, 105-113. [CrossRef]

18. Lee, H.; León, J.; Raskin, I. Biosynthesis and metabolism of salicylic acid. Proc. Natl. Acad. Sci. USA 1995, 92, 4076-4079. [CrossRef] [PubMed]

19. Rejeb, I.B.; Pastor, V.; Mauch-Mani, B. Plant responses to simultaneous biotic and abiotic stress: Molecular mechanisms. Plants 2014, 3, 458-475. [CrossRef] [PubMed]

20. Guo, H.; Dang, X.; Dong, J. Hydrogen peroxide and nitric oxide are involved in salicylic acid-induced salvianolic acid B production in Salvia miltiorrhiza cell cultures. Molecules 2014, 19, 5913-5924. [CrossRef] [PubMed] 
21. Elwan, M.W.M.; El-Hamahmy, M.A.M. Improved productivity and quality associated with salicylic acid application in greenhouse pepper. Sci. Hortic. 2009, 122, 521-526. [CrossRef]

22. Dong, C.-J.; Wang, X.-L.; Shang, Q.-M. Salicylic acid regulates sugar metabolism that confers tolerance to salinity stress in cucumber seedlings. Sci. Hortic. 2011, 129, 629-636. [CrossRef]

23. Asmaa, R.A.E.H.; Ahmed, M.A.; Karima, M.G.E.D.; Magda, A.S.; Hoda, M.E. Role of salicylic acid to improve physiological characters and bio-chemical markers of soybean (Glycine max L.) under sea salt stress. Int. J. Environ. Res. 2017, 11, 547-556. [CrossRef]

24. Bideshki, A.; Arvin, M.J. Effect of salicylic acid (SA) and drought stress on growth bulb yield and allicin content of garlic (Allium sativum) the field. J. Plant Econ. Physiol. 2010, 2, 73-79.

25. Bagherifard, A.; Bagheri, A.; Sabourifard, H.; Bagherifard, G.; Najar, M. The effect of salicylic acid on some morphological and biochemistry parameters under salt stress in Herb Artichoke (Cynara scolymus L.). Res. J. Fish. Hydrobiol. 2015, 10, 745-750.

26. Hayat, Q.; Hayat, S.; Irfan, M.; Ahmad, A. Effect of exogenous salicylic acid under changing environment: A review. Environ. Exp. Bot. 2010, 68, 14-25. [CrossRef]

27. Sahar, K.; Amin, B.; Taher, N.M. The salicylic acid effect on the Salvia officianlis L. sugar, protein and proline contents under salinity ( $\mathrm{NaCl}$ ) stress. J. Stress Physiol. Biochem. 2011, 7, 80-87.

28. Stratu, A.; Lobiuc, A. The influence of lead on seed germination and seedlings growth of Ocimum basilicum L. and Salvia coccinea Buchoz ex Etl. species. Analele Stiin. Ale Univ. 2015, 61, 39-47.

29. Ljubojević, M.; Ognjanov, V.; Maksimović, I.; Čukanović, J.; Dulić, J.; Szabò, Z.; Szabò, E. Effects of hydrogel on growth and visual damage of ornamental Salvia species exposed to salinity. Clean Soil Air Water 2017, 45, 1600128. [CrossRef]

30. Radhika, J.; Pazhanithambi, G.; Brindha, P. Antioxidant and free radical scavenging property of Salvia coccinea Buc'Hoz. Biomedicine 2009, 29, 52-55.

31. Yadav, S.; Mukundan, U. In vitro antioxidant properties of Salvia coccinea Buc'hoz ex Etl. and Salvia officinalis L. Indian J. Fundam Appl. Life Sci. 2011, 1, 232-238.

32. Bilgin, M.; Sahin, S.; Dramur, M.U.; Sevgili, L.M. Obtaining scarlet sage (Salvia coccinea) extract through homogenizer- and ultrasound-assisted extraction methods. Chem. Eng. Comm. 2013, 200, 1197-1209. [CrossRef]

33. Ghasemzadeh, A.J.; Hawa, Z.E. Interactive effect of salicylic acid on some physiological features and antioxidant enzymes activity in ginger (Zingiber. officinale Roscoe). Molecules 2013, 18, 5965-5979. [CrossRef] [PubMed]

34. Sahu, G.K. Salicylic acid: Role in plant physiology and stress tolerance. In Molecular Stress Physiology of Plants; Rout, G.R., Das, A.B., Eds.; Springer: New Delhi, India, 2013; pp. 217-239.

35. Rivas-San Vicente, M.; Plasencia, J. Salicylic acid beyond defence: Its role in plant growth and development. J. Exp. Bot. 2011, 62, 3321-3338. [CrossRef] [PubMed]

36. Manaa, A.; Gharbi, E.; Mimouni, H.; Wasti, S.; Aschi-Smiti, S.; Lutts, S.; Ahmed, H.B.A. Simultaneous application of salicylic acid and calcium improves salt tolerance in two contrasting tomato (Solanum lycopersicum) cultivars. S. Afr. J. Bot. 2014, 95, 32-39. [CrossRef]

37. Salachna, P.; Piechocki, R.; Zawadzińska, A.; Wośkowiak, A. Response of speckled spur-flower to salinity stress and salicylic acid treatment. J. Ecol. Eng. 2015, 16, 68-75. [CrossRef]

38. Parida, A.K.; Das, A.B. Salt tolerance and salinity effects on plants: A review. Ecotoxicol. Environ. Saf. 2005, 60, 324-349. [CrossRef] [PubMed]

39. Gengmao, Z.; Quanmei, S.; Yu, H.; Shihui, L.; Changhai, W. The physiological and biochemical responses of a medicinal plant (Salvia miltiorrhiza L.) to stress caused by various concentrations of NaCl. PLoS ONE 2014, 9, e89624. [CrossRef] [PubMed]

40. Negrão, S.; Schmöckel, S.M.; Tester, M. Evaluating physiological responses of plants to salinity stress. Ann. Bot. 2017, 119, 1-11. [CrossRef] [PubMed]

41. Chaves, M.M.; Flexas, J.; Pinheiro, C. Photosynthesis under drought and salt stress: regulation mechanisms from whole plant to cell. Ann. Bot. 2009, 103, 551-556. [CrossRef] [PubMed]

42. Tehami, W.; Kherraf, A.; Boufeldja, W.; Mahmoud, M.; Ghislaine, A.; Abbouni, B.; Benali, M. Determination of primary and functional metabolites of Salvia argentea and evaluation of its leaves and roots antioxidant activity. Der Pharma Chem. 2016, 8, 1-6. 
43. Ksouri, R.; Megdiche, W.; Debez, A.; Falleh, H.; Grignon, C.; Abdelly, C. Salinity effects on polyphenol content and antioxidant activities in leaves of the halophyte cakile maritima. Plant Physiol. Biochem. 2007, 45, 244-249. [CrossRef] [PubMed]

44. Taârit, M.B.; Msaada, K.; Hosni, K.; Marzouk, B. Fatty acids, phenolic changes and antioxidant activity of clary sage (Salvia sclarea L.) rosette leaves grown under saline conditions. Ind. Crops Prod. 2012, 38, 58-63. [CrossRef]

45. Valifard, M.; Mohsenzadeh, S.; Kholdebarin, B.; Rowshan, V. Effects of salt stress on volatile compounds, total phenolic content and antioxidant activities of Salvia mirzayanii. S. Afr. J. Bot. 2014, 93, 92-97. [CrossRef]

46. Thiruvengadam, M.; Kim, S.-H.; Chung, I.-M. Exogenous phytohormones increase the accumulation of health-promoting metabolites, and influence the expression patterns of biosynthesis related genes and biological activity in Chinese cabbage (Brassica rapa spp. pekinensis). Sci. Hortic. 2015, 193, 136-146. [CrossRef]

47. Wang, Z.; Ma, L.; Zhang, X.; Xu, L.; Cao, J.; Jiang, W. The effect of exogenous salicylic acid on antioxidant activity, bioactive compounds and antioxidant system in apricot fruit. Sci. Hortic. 2015, 181, 113-120. [CrossRef]

48. Lichtenthaler, H.K.; Wellburn, A.R. Determinations of total carotenoids and chlorophylls a and b of leaf extracts in different solvents. Biochem. Soc. Trans. 1983, 11, 591-592. [CrossRef]

49. Wojdyło, A.; Oszmiański, J.; Czemerys, R. Antioxidant activity and phenolic compounds in 32 selected herbs. Food Chem. 2007, 105, 940-949. [CrossRef]

50. Andrys, D.; Kulpa, D.; Grzeszczuk, M.; Bihun, M.; Dobrowolska, A. Antioxidant and antimicrobial activities of Lavandula angustifolia Mill. field-grown and propagated in vitro. Folia Hort. 2017, 29, 161-180. [CrossRef]

51. Chew, K.K.; Khoo, M.Z.; Ng, S.Y.; Thoo, Y.Y.; Wan Aida, W.M.; Ho, C.W. Effect of ethanol concentration, extraction time and extraction temperature on the recovery of phenolic compounds and antioxidant capacity of Orthosiphon stamineus extracts. Int. Food Res. J. 2011, 18, 1427-1435.

52. Re, R.; Pellegrini, N.; Proteggente, A.; Pannala, A.; Yang, M.; Rice-Evans, C. Antioxidant activity applying an improved ABTS radical cation decolorization assay. Free Radic. Biol. Med. 1999, 26, 1231-1237. [CrossRef]

Sample Availability: Samples of the compounds are not available from the authors.

(C) 2018 by the authors. Licensee MDPI, Basel, Switzerland. This article is an open access article distributed under the terms and conditions of the Creative Commons Attribution (CC BY) license (http://creativecommons.org/licenses/by/4.0/). 